\title{
How Education Makes Us Healthy[1]
}

\author{
CATHIE HAMMOND
}

Centre for Research into the Wider Benefits of Learning, Institute of Education, University of London, UK

\begin{abstract}
The evidence for positive correlations between years of education and health status is consistent. The patterns of causalities underlying these correlations are likely to be complex, but here the focus is upon one direction of causality; namely how education makes us healthy. If education has the potential to improve health outcomes, then policy-makers and practitioners should understand the interrelated processes involved. As a first step towards this understanding, I suggest a typology of intermediate factors linking education to health outcomes, falling under four headings; economic factors, access to health services, health-related practices, and coping with stress. Although the development of the typology was the purpose of the research, the process of doing so led to the identification of a number of policy-relevant issues or themes that apply to all groups of intermediate factors: (1) immediate psychosocial outcomes of learning play a fundamental role in generating the behaviours, skills and personal attributes that have lasting effects upon health; (2) health benefits of education that apply to individuals do not always apply to communities; (3) health benefits of education depend upon the nature of the learning experienced; and (4) they also depend upon the social and economic structures in which the learner is situated.
\end{abstract}

\section{Introduction}

Government-funded initiatives in Britain such as the National Healthy School Standard and the education streams of Health Action Zones are based upon a premise that education can lead to improvements in health. This paper briefly reviews the evidence base for such a premise and investigates the intermediate factors that link education with health outcomes.

As we shall see below, other authors have reviewed the evidence relating to correlations and causal connections between education and health, but there is little debate and few empirical studies concerning the processes through which education (as opposed to health education) affects health conditions. The processes involved are likely to be interrelated, not only with one another but also with the type of learning provision, characteristics of the learners, and social, political and economic factors. No attempt is made here to fully model these interrelationships. Instead, a simple typology of intermediate factors linking education to health outcomes is presented as a basis for further debate and research.

Because intermediate factors linking education to health outcomes were not predefined, those literatures relevant to the development of the typology could not be predefined either. Consequently, the evidence presented here was not selected in a way that is typical of a rigorous and systematic literature review because it was not drawn from a specified 
sampling frame. Rather, the approach has been exploratory, the objective being to develop the typology of intermediate factors through gaining an overview of the literatures which relate to education and its outcomes, and health and its determinants.

These literatures come from various fields: education, economics of education, sociology of medicine, health promotion, health psychology, social psychology of health, and sociology. Texts were selected on the advice of experts because they are perceived to be central to each field. An extensive search of academic papers was also made using the Bath Information and Data Services (BIDS) with search terms encompassing education and learning plus a range of health conditions, health behaviours and psychosocial qualities, for papers dating back to 1998. As the typology developed, additional search terms were included. Thus selection of the evidence and the development of the typology took place together as an iterative process.

The terms 'education' and 'learning' are used here interchangeably, and encompass all learning that is intentional, regardless of whether it is taught or untaught. Clearly, the health effects of education depend upon its nature and timing, and the characteristics of the learner, and so far as possible these differences are investigated. However, most quantitative studies measure learning by years of formal education or highest qualification gained and apply to nationally representative samples rather than to specific groups, which limits the scope of the review.

The evidence for a correlation (i.e., an association without the direction of causality being specified) between education and physical health has been reviewed (see Ross \& Mirowsky, 1999; Grossman \& Kaestner, 1997) and the overwhelming conclusion is that the evidence for a correlation is consistent:

A number of studies in the United States suggest that years of formal schooling completed is the most important correlate of good health. (Grossman \& Kaestner, 1997, p. 73)

Evidence for the correlation has been found worldwide and amongst individuals of different ethnic groups, ages and incomes. In addition, education appears to correlate with lower rates of depression and suicide. See Hammond (2002) for more details of these studies.

In contrast, a number of studies have found positive associations between education and rates of neurotic disorders. For example, amongst a sample born in St. Louis, USA, during the 1910s and 1920s, educational success was associated with the onset and progression of neurotic disorders in later life (Benham \& Benham, 1982). In addition, studies of the epidemiology of anorexia nervosa in Britain up until the 1980s consistently found the condition to be more prevalent amongst individuals of higher socio-economic status, which correlates with level of education (see Dally et al., 1979; Crisp, 1980). On the other hand, a more recent community-based study of patients with a diagnosis of anorexia nervosa in Glasgow between 1979 and 1983 found that the class distribution of patients did not differ from that of the general community (Leighton \& Millar, 1985). One explanation for the changing epidemiology of the condition that has been suggested by experts in the field is that access to education that was once restricted to the most affluent groups has diffused through the population (Gordon, 1990). In other words, social class is not such a good proxy measure for educational experience and achievement as it used to be. (Other suggested explanations are changing patterns in diagnosis-as opposed to epidemiology, changing attitudes towards female achievement, and increasing media emphasis on the attractiveness of thinness amongst females (Gordon, 1990).)

Research relating more specifically to educational success has found that amongst the spectrum of psychiatric disorders, those who are educationally successful are particularly 
likely to develop anorexia nervosa and other eating disorders, as opposed to other conditions. For example, Toro et al. (1995) used data from the clinical records of 185 Spanish adolescents aged between 11 and 18 years who were diagnosed with anorexia nervosa, and compared these data with data from a group of 185 psychiatric patients without anorexia nervosa, matched by sex, age, centre, and time of consultation. The comparisons showed that patients with anorexia nervosa perform much better academically than other psychiatric patients, and that their parents have a higher standard of education. Similar findings are reported by Westermeyer and Specker (1999).

There are three ways of explaining correlations between education and health. The first is that individuals with better health are likely to continue in education for longer. The second is that one or more factors, for example family background variables, affect both education and health outcomes. The third is that education improves health. A full review by Grossman and Kaestner (1997) suggests that there is evidence that all three kinds of causality contribute to the observed correlations between education and health. Here, the focus is upon the effects of education upon health.

The hypothesis that education causes changes in health can be tested using quantitative analyses of longitudinal data-sets. Longitudinal data-sets include the life histories of individuals and so it is possible to investigate relationships between education and subsequent health status, controlling for early indicators of health. In addition, it is possible to control for background variables like family income that could affect both success in education and health. Including these variables, which are referred to as confounding variables, reduces the magnitudes of correlations that are found between education and health, but a greater proportion of the remaining correlations are likely to be accounted for by effects of education upon health.

Although these approaches might provide evidence that effects do not exist, they cannot provide positive evidence that effects do exist. This is because it is impossible to be sure that every confounding variable has been included in the analysis - partly because researchers might not think of all the relevant variables, and partly because not all those variables that are relevant are accurately measured in the data-sets. Consequently, magnitudes of correlations based upon analyses of longitudinal data-sets might be interpreted as the upper bounds of effects.

Studies investigating the causal effect of education upon health have been reviewed by Grossman and Kaestner (1997), Hartog and Oosterbeek (1998) and others, and the authors agree that there is consistent evidence that education has positive effects upon health. Here, just two studies are described, because they are recent ones using British data-sets.

Cohort studies of adults born in Britain in 1958 and 1970 have been analysed in attempts to isolate the health effects of education. Bynner and Egerton (2001), using regression models, report evidence for associations between gaining a degree-level qualification and health outcomes later in life. The measures for health include risk of depression, self-rated general health and risk of assault and accidents, and the correlations persist even when parental education, parental occupation, family income, housing, employment status, partner's education and cognitive skills at age 11 are controlled for. However, health status prior to participation in higher education is not included in the analyses and so the argument that healthier individuals are more inclined to pursue and succeed in higher education cannot be ruled out as an explanation for the observed correlations.

Feinstein $(2001,2002)$ analysed the same data-sets using a statistical technique (propensity score matching), which, under appropriate conditions, can be particularly effective for isolating effects. Unlike Bynner and Egerton, Feinstein includes in his analyses not only background variables and childhood abilities, but also physical and mental health 
in childhood. He investigates the separate effects of academic and vocational qualifications upon the chances of experiencing depression and respiratory problems, obesity, level of exercise and self-reported good and bad health.

The studies report effects of academic and vocational qualifications that are statistically significant for all health outcomes, but these effects are not universal. They vary depending upon the particular health outcome, the individual's year of birth (which is a measure of their age at the time when health outcomes were assessed and also of the period during which they experienced each stage of their life), their gender, whether a qualification is academic or vocational, and the change in qualification level. For example, Feinstein found that academic qualifications have protective effects against the onset and progression of respiratory problems in the older but not the younger cohort, which may reflect the cumulative effects of health practices such as smoking. Academic qualifications had a strong protective effect against depression for women but not for men born in 1970, although for the 1958 cohort smaller but statistically significant protective effects against depression were found for both men and women. Generally, when confounding bias is dealt with using the matching method, changes in qualification at relatively low levels had more effect upon health outcomes than changes in qualification levels where the initial level was relatively high. Some figures indicating the sizes of identified effects are presented in Table 1.

Findings that the health effects of education vary across health outcomes, previous levels of education, age, and gender are relevant to policy decisions concerning investments in education targeted towards particular groups of learners. However, such decisions should be more fully informed by understanding of the processes through which education affects health outcomes. As a contribution to this understanding, we now examine evidence for intermediate factors linking education to health outcomes and suggest a simple typology.

Table 1 Relationships between academic qualifications and health

\begin{tabular}{|c|c|c|c|c|c|c|c|c|c|c|}
\hline \multirow{2}{*}{$\begin{array}{l}\text { qualification } \\
\text { levels }\end{array}$} & depression & \multicolumn{2}{|c|}{$\begin{array}{c}\text { respiratory } \\
\text { problems }\end{array}$} & obesity & \multicolumn{2}{|c|}{$\begin{array}{l}\text { taking } \\
\text { exercise }\end{array}$} & \multicolumn{2}{|c|}{$\begin{array}{l}\text { good self- } \\
\text { reported } \\
\text { health }\end{array}$} & \multicolumn{2}{|c|}{$\begin{array}{l}\text { poor self- } \\
\text { reported } \\
\text { health }\end{array}$} \\
\hline & men women & men & women & men women & men & women & men & women & men & women \\
\hline \multicolumn{11}{|l|}{1958 cohort } \\
\hline 0 to 1 & $\begin{array}{ll}-4 & -6\end{array}$ & & & -5 & & & & & & -10 \\
\hline 0 to 2 & not reported & -6 & -10 & not reported & & & 5 & 6 & & \\
\hline \multicolumn{11}{|l|}{1 to 2} \\
\hline 2 to 3 & & & -8 & & 10 & 8 & 7 & & -5 & \\
\hline 3 to 4 & & -7 & & -7 & & & & 10 & 5 & \\
\hline \multicolumn{11}{|l|}{1970 cohort } \\
\hline 0 to 1 & -10 & & & -7 & & & & & & \\
\hline 0 to 2 & not reported & & & not reported & 4 & 5 & 5 & 4 & & -9 \\
\hline 1 to 2 & & & & & 14 & & 10 & & & \\
\hline 2 to 3 & & & & & & & & & 10 & \\
\hline 3 to 4 & -6 & & & & & & & & & \\
\hline
\end{tabular}

Note: Values are differences between the percentages of men/women reporting each health outcome at the two levels of qualification. All the associations that are statistically significant at the level of $p<0.05$ are reported, i.e. the chances that the observed correlation (or effect) happened by chance is less than 1 in 20 .

Source: Taken from Feinstein, 2001, 2002. 


\section{Intermediate Factors that Link Education with Health Outcomes}

Four groups of factors are described in this section. They fall under the headings of economic factors, access to health services, health-related practices, and coping with stress.

\section{Economic Factors}

Channels of causality that involve economic factors appear to account for a substantial part of the effect of education upon health. Ross and Mirowsky (1999) analysed data collected in a national telephone survey of US households, which over-represented adults over 60, but which was otherwise representative of the US population. The authors fitted regression models to estimate the extents to which hypothesised variables predicted levels of physical functioning and perceived health. They report that years of education is associated with both measures of health, and that just under half of this association is mediated by work and economic conditions.

There is strong evidence that educational success is associated with higher earnings, higher occupational status and lower rates of unemployment (see Johnes, 1993; Asplund \& Pereira, 1999). Each of these economic outcomes is associated with better physical and mental health (e.g. Marmot et al., 1991; Wilkinson, 1996; Hemingway et al., 2000).

The gradient between health and socio-economic status is usually referred to as health inequality. Although individuals with better health, or with characteristics that predispose them to better health later in life, may also tend to be successful in socio-economic terms, it is highly plausible that the gradient is to some extent explained by effects of socioeconomic status upon health. Wilkinson (1996) suggests that unemployment, low income and low occupational status induce feelings of insecurity, low self-efficacy, and a lack of fulfilment, which increase levels of chronic stress and have negative effects upon mental and physical health.

To the extent that education raises individuals out of low status occupations and removes them from occupational insecurity, it will improve their health, but it will not help those who are left behind (see Hirsch, 1977). In other words, this aspect of education benefits individuals but does not challenge existing economic inequalities. On the other hand, increased knowledge and skills gained through education may lead to economic growth, and it has been argued that economic growth in the long term benefits all members of society (referred to as 'trickle down' economics — see Fink, 1982; Krugman, 1994; and Albelda et al., 1988 for fuller discussions). Whether this highly contentious argument is accepted or not, it is still the case that occupational and economic status raised through education benefits successful individuals only in any immediate and direct way. Primarily, it is a private rather than a public benefit.

The argument above that education contributes to socio-economic success, which in turn leads to improved health outcomes needs qualification because the ways in which economic factors link education with health outcomes depend upon political, economic and cultural factors. This is illustrated by findings reported by Hartog and Oosterbeek (1998), who analysed data from a cohort of adults born in 1940 in Holland. The authors found positive correlations between qualification levels, wealth, health and happiness up to an intermediate level of qualification only, higher levels of qualifications not being associated with increased health, wealth or happiness. One explanation for the finding is that for this cohort, intermediate levels of qualification translated later in life into the same levels of economic success as higher levels of qualification.

Other findings that can be explained by a similar argument are reported by Veenhoven in a study of the determinants of well-being (1996). Veenhoven reviews the evidence for 
correlations between education and well-being and reports that whereas education and wellbeing are positively correlated in poorer countries, the magnitudes of such correlations diminish in wealthier countries, and in some studies disappear altogether. Veenhoven suggests that these findings reflect a lack of high-level jobs in wealthier countries, in relation to the numbers receiving high levels of education.

Two studies provide evidence relating to the experience of highly qualified individuals living in Britain, for whom, according to the explanation given by Veenhoven there may be a paucity of appropriate jobs. Both studies use data representative of adults living in households in Britain in 1991. Clarke and Oswald (1994), investigating the experience of people who are unemployed, report that amongst this group those with higher qualifications are particularly likely to experience depression. One explanation for the correlation is that amongst the highly qualified, those who are prone to becoming unemployed are also prone to depression. Another plausible explanation is that the experience of unemployment is particularly difficult to cope with for people with high levels of qualification because expectations raised through educational success have not been met, and so the degree of cognitive dissonance (the difference between expectations and experience) that individuals have to overcome is particularly high.

The second study investigates relationships between occupation and occupational stress and reports that professional-managerial occupations, in which well-educated individuals are over-represented, are associated with relatively high levels of occupational stress, which, over long periods is likely to have damaging effects upon health (Rose, 2000). The association between high level occupations and high levels of occupational stress may reflect insecure job markets which emphasise accountability.

Taken together, these findings highlight the need for educational policies that make sense within wider economic and political contexts. If, for example, education develops individuals' autonomy and social responsibility, is it fair afterwards to expect them to work in occupations where they lack the opportunities to exercise these qualities? Also, if the economic structure of a country is levelling out amongst the most successful-or if there is a political will for this to happen-then to what extent should the education system emphasise the measurement of relative achievement levels (as opposed to achievement in different areas) amongst those who all achieve highly? This question is topical at the time of writing because of allegations that 'A' level grades were tampered with in Britain to ensure that only a small proportion of candidates achieved top grades.

\section{Access to Health Services}

The 'inverse-care law' describes the phenomenon that those living in areas of deprivation characterised by poor health tend to receive least health care provision (Hart, 1971). Those who have fewer health care needs and receive better provision in response to them tend to be of higher socio-economic status with higher levels of education. Better access to health services may result partly from the effects of education upon understanding and evaluating the plethora of health and health service messages in the mass media, and the ability to communicate effectively with health care professionals and elicit their help.

This is illustrated particularly sharply in relation to conditions for which the patient's understanding of their symptoms and their ability to communicate effectively with health professionals affect access to appropriate treatment. Poorly understood conditions, like chronic fatigue syndrome or myalgic encephalomyelitis (CFS/ME) fall into this category. Studies of the epidemiology of CFS/ME which use samples selected from patients attending hospital clinics find that the condition is more common amongst individuals of higher socio-economic status (Wessely et al., 1998). In contrast, community-based studies have 
failed to find evidence of a gradient across socio-economic status in the prevalence rates of CFS/ME (Buchwald et al., 1995; Shefer et al., 1997; Lawrie \& Pelosi, 1995). It is likely that the apparently contradictory findings reflect selection biases in symptom attribution, diagnosis, and referral to hospital clinics (Wessely et al., 1998). Biases of this sort are likely to apply to the diagnosis of other poorly understood conditions such as atopic disorders (more commonly referred to as allergies), which appear to be diagnosed more often in children whose parents are highly educated (Heinrich et al., 1998), and it has been suggested that in the past they applied to anorexia nervosa (Gordon, 1990).

Difficulties in obtaining an acceptable diagnosis and appropriate treatment lead to the formation of pressure groups. These groups reinforce individuals' attempts to obtain their medical rights and help to ensure that high quality services are made available to all those who face similar difficulties. What is relevant here is that membership of such pressure groups is dominated by individuals with education. For example, in relation to CFS/ME, Wessely et al. state, 'Too many studies to list show that the typical patient joining a self-help organisation, comes from the upper social classes' (1998, p. 147).

A patient's education may determine not only access to appropriate medical treatment but also its effectiveness. This is because patients with more education appear to be better informed and advised about the nature and management of their illnesses and are also more likely to adhere to medical advice (Hagoel et al., 1999; Amonkar et al., 1999; Kyngas \& Lahdenpera, 1999; Peyrot et al., 1999; Rudman et al., 1999).

The impact of education upon access to health services benefits the health of individuals, but it is less clear that it benefits the whole community. On one hand, the collective action of pressure groups, which tend to be made up of more rather than less educated individuals, may result in improved access to services for all members of a particular group. But where diagnosis and treatments are not completely straightforward (as is often the case), the allocation of limited resources appears to be determined partly by ability to work an overcomplicated or alien (to some) system as well as by measures of need. Where education benefits health through enabling individuals to work the system more effectively, it benefits health at an individual level but it does not change the system, and because it benefits those who are already advantaged (educationally), it reinforces existing inequalities.

\section{Health-related Practices}

Health-related practices include taking exercise, eating a healthy diet, dental hygiene, abstinence from smoking, moderate consumption of alcohol and other drugs, not driving whilst intoxicated, use of seat belts, use of condoms, and medical adherence. These practices appear to be positively correlated with one another (see Costakis et al., 1999; Feigelman et al., 1998; Kyngas \& Lahdenpera, 1999).

Health practices impact upon both physical and mental health (see Kendler et al., 1999). In addition, the adoption of health practices correlates with measures of education. Details of some relevant studies are summarised in Table 2, below.

Why do more educated people tend to behave in healthier ways than their less educated counterparts? Learning may promote healthy practices, but in addition, background variables may incline individuals both to adopt healthy practices and to pursue their education. It is also likely that healthy practices play a role in the achievement of educational success and/or the choice of educational path. Studies of the health-related practices of adolescents do not distinguish between these directions of causality. For example, Karvonen et al. (1999) examined the relationships between social mobility and health-related behaviours amongst 16- and 18-year-olds living in Finland. A clear and consistent finding 


\begin{tabular}{ll}
$\begin{array}{l}\text { Health-related practice associated } \\
\text { with education }\end{array}$ & References \\
\hline Healthy diet & $\begin{array}{c}\text { Braddon et al. (1988); Ippolito \& Mathius (1990); Schafer et al. } \\
(1999)\end{array}$ \\
Fhysical exercise & $\begin{array}{l}\text { Frisk et al. (1997); Ross \& Mirowsky (1999); Kubzansky et al. } \\
(1999)\end{array}$ \\
Moderate drinking (as opposed to & Van Oers et al. (1999); Berggren \& Sutton (1999); Ross \& \\
excessive drinking or abstinence) & Mirowsky (1999) \\
Smoking less and/or giving up smoking & Kubzansky et al. (1999); Sander (1995a); Sander (1995b); Kendler \\
& et al. (1999); Jorm et al. (1999) \\
Use of condoms & Kasenda et al., 1997 \\
Use of seat belts & Leigh, 1990 \\
Adherence to medical instructions & Hagoel et al. (1999); Amonkar et al. (1999); Kyngas \& Lahdenpera \\
& $(1999) ;$ Peyrot et al. (1999); Rudman et al. (1999)
\end{tabular}

was that health-related practices were associated with achieved social position, which was measured using educational status and attainment, in combination with labour market status. However, the authors remark that the causalities underlying this finding are unclear. They suggest that a combination of explanations is likely-engaging early in healthcompromising behaviours may influence school performance, and in addition, educational success, or the lack of it, leads young people into groups in which they tend to adopt practices that are viewed as normal.

Below, I focus upon the impact of learning on health-related attitudes and practices and the mechanisms through which this direction of causality might operate.

Early models of the determinants of health practices emphasised the importance of raising awareness of health information (such as the 'Health Belief Model' and the 'Theory of Reasoned Action'-see Crossley, 2000). Mainstream education appears to raise such awareness (Teisl et al., 1999; Mirowsky \& Ross, 1998). However, awareness explains only a small part of the impact of education upon health. Kenkel (1991) analysed US data from the Health Promotion/Disease Prevention Supplement to the 1985 National Health Interview Survey $(n>33,000)$ using econometric methods. He reports that health knowledge about alcohol use, smoking and exercise only accounted for 5-20\% of the correlation found between education and these health practices, after controlling for additional explanatory variables reflecting age, race, family income, marital status, employment status and selfreported stress levels. This finding resonates with theoretical and practical developments in health promotion, which currently emphasise the importance of empowerment and contextual factors over simple awareness-raising (Kickbush, 1990; Kippax \& Crawford, 1993; Campbell, 1999).

There is evidence that a sense of belonging to a wider community, social support and civic engagement are outcomes of learning (see Table 3), and also that these social outcomes reinforce healthy behaviours. Putnam reviews the evidence and suggests that socially isolated people are more likely to smoke, drink, overeat, and engage in other health-damaging practices (2000, p. 327). In addition, health promotion interventions emphasise the importance of peer norms in the adoption of healthy practices (Campbell \& Mzaidume, 2001, 2002). Clearly, the socialising aspect of education has tremendous potential to promote healthy practices. This potential is recognised in the National Healthy Schools Standard, which seeks to develop in secondary schools an ethos that promotes 
Table 3 Details of some studies that find that learning contributes to social integration and social capital

\begin{tabular}{|c|c|c|c|c|c|}
\hline Outcome of Learning & Country & Learners & Learning provision & Methodological approach & Reference \\
\hline \multirow{9}{*}{$\begin{array}{l}\text { Sense of belonging } \\
\text { to a wider } \\
\text { community, anti- } \\
\text { discriminatory } \\
\text { attitudes and } \\
\text { interpersonal trust }\end{array}$} & Various European & Adults & Formal education & Review & Emler \& Frazer, 1999 \\
\hline & Countries & Adults & Formal education & Quantitative, qualitative & Wagner \& Zick, 1995 \\
\hline & UK & $\begin{array}{l}\text { Adults with mental health } \\
\text { difficulties }\end{array}$ & Community adult education & Review of studies & Wertheimer, 1997 \\
\hline & UK & Adults & Higher education & Quantitative & Bynner \& Egerton, 2001 \\
\hline & England & Adults & Further education & Quantitative \& qualitative & Preston \& Hammond, 2002 \\
\hline & England & Older adults & Summer university & Qualitative & Jarvis \& Walker, 1997 \\
\hline & England & $\begin{array}{l}\text { Adults with mental health } \\
\text { difficulties }\end{array}$ & Various & Programme evaluation & McGivney, 1997 \\
\hline & US & US high school students & 'Sport for Peace' & Programme evaluation & Ennis et al., 1999 \\
\hline & US & US high school students & Formal education & Analysis of records & Angell, 1983 \\
\hline \multirow{3}{*}{$\begin{array}{l}\text { Supportive } \\
\text { relationships }\end{array}$} & UK & Adults & Higher education & Quantitative & Bynner \& Egerton, 2001 \\
\hline & Netherlands & Adults aged $55+$ & Mentoring & Programme evaluation & Kocken \& Voorham, 1998 \\
\hline & US & Adults & Formal education & Quantitative & Ross \& Mirowsky, 1999 \\
\hline \multirow{2}{*}{$\begin{array}{l}\text { Civic engagement } \\
\text { and activity }\end{array}$} & Various & Adults & Formal education & Review & Emler \& Frazer, 1999 \\
\hline & UK & Adults & Higher education & Secondary Analysis & Parry et al., 1992 \\
\hline \multirow{3}{*}{$\begin{array}{l}\text { Political engagement } \\
\text { and activity }\end{array}$} & UK & Young adults aged 15 to 20 & Formal education & Quantitative & Banks et al., 1992 \\
\hline & UK & Young adults & $\begin{array}{l}\text { Formal education, Parental } \\
\text { education }\end{array}$ & Quantitative & Bynner \& Ashford, 1994 \\
\hline & UK & Adults & Higher Education & Quantitative & Bynner \& Egerton, 2001 \\
\hline Social capital & Various & Adults & Various & Review & Glaeser, 2000 \\
\hline
\end{tabular}


empowerment, respect, and social responsibility, and within this context provides health information and guidance.

Self-efficacy - 'the extent to which people see themselves as being in control of the forces that importantly affect their lives’ (Pearlin et al., 1981, p. 339), self-esteem, and thinking in terms of the future as well as the here-and-now are outcomes of learning that have a major impact upon health-related practices. These contribute to empowerment, which is emphasised as an important factor in the adoption of healthy practices in the health promotion literature.

Thinking in terms of future outcomes (sometimes referred to as future orientation or time preference) may be developed through the study of history and thinking about adulthood and imagined scenarios at school (Becker \& Mulligan, 1994). However, although empirical studies have found associations between level of education, health behaviours and measures of future orientation, they do not provide evidence about causalities. For example, based upon analyses of US data, Kendler et al. (1999) report that nicotine dependence is related to personality characteristics reflecting future orientation, namely mastery, selfesteem, locus of control, and dispositional optimism. Leigh and Dhir (1997) find an association between years of schooling and exercise amongst men aged 65 and over living in the USA, after controlling for parental levels of education, family wealth during childhood, and area of residence during childhood, and report that the association is partially mediated by patience, self-efficacy and risk preference.

Ross and Mirowsky (1999) suggest how self-efficacy may lead to the adoption of healthy practices:

The sense of personal control improves health partially through health-enhancing behaviours. Compared with people who feel powerless to control their lives, people with a sense of personal control know more about health, are more likely to initiate preventive behaviours like quitting smoking, exercising, or moderating alcohol consumption, and, in consequence, have better self-rated health, fewer illnesses, and lower rates of mortality. In contrast, lack of personal control makes efforts seem useless; if outcomes are beyond one's control, why exercise, quit smoking, or avoid overweight? (p. 446)

More recent studies indicate that self-efficacy and self-esteem are indeed associated with healthier eating habits (Callaghan, 1998), freedom from nicotine dependence (Kendler et al., 1999), renal compliance, and glycemic control (Rudman et al., 1999).

Possibly the most commonly attributed psychological outcome of education is confidence. A large-scale fieldwork project involving over 140 biographical interviews with adults living in England plus group interviews with practitioners providing different forms of adult learning concludes that:

The most fundamental and pervasive benefit from learning of every kind is a growth in self-confidence. (Schuller et al., 2002, p. 14)

Dench and Regan (1999) survey the literature relating to the wider benefits of learning and conclude:

What does emerge from the literature overall is evidence of a range of positive impacts of learning, especially on more general well being and self-esteem. (p. 7)

Details of some additional studies are given in Table 4 . 
Table 4 Details of studies that find that learning leads to self-efficacy and self-esteem

\begin{tabular}{|c|c|c|c|c|c|}
\hline Outcome of learning & Country & Learners & Learning provision & Methodological approach & Reference \\
\hline Self-understanding & $\begin{array}{l}\text { England } \\
\text { England }\end{array}$ & $\begin{array}{l}\text { Mature women } \\
\text { Adults }\end{array}$ & $\begin{array}{l}\text { Higher education } \\
\text { Higher education and Access }\end{array}$ & $\begin{array}{l}\text { Qualitative individual interviews } \\
\text { Qualitative }\end{array}$ & $\begin{array}{l}\text { Cox \& Pascall, } 1994 \\
\text { West, } 1995\end{array}$ \\
\hline \multirow[t]{2}{*}{ Self-esteem } & $\begin{array}{l}\text { England } \\
\text { Britain } \\
\text { US }\end{array}$ & $\begin{array}{l}\text { Adults } \\
\text { Older adults } \\
\text { Older adults }\end{array}$ & $\begin{array}{l}\text { 'New beginnings' courses } \\
\text { Informal learning } \\
\text { Mentees in psychosocial support } \\
\text { programme }\end{array}$ & $\begin{array}{l}\text { Interviews, questionnaires } \\
\text { Qualitative } \\
\text { Questionnaire }\end{array}$ & $\begin{array}{l}\text { Hull, } 1998 \\
\text { Carlton \& Soulsby, } 1999 \\
\text { Koberg et al., } 1998\end{array}$ \\
\hline & US & $\begin{array}{l}\text { Pregnant women (white and } \\
\text { Hispanic) }\end{array}$ & Highest qualification & Interviews, questionnaires & Rini et al., 1999 \\
\hline \multirow[t]{5}{*}{$\begin{array}{l}\text { Self-esteem and } \\
\text { self-efficacy }\end{array}$} & $\begin{array}{l}\text { England \& Wales } \\
\text { England \& Wales }\end{array}$ & $\begin{array}{l}\text { Adults } \\
\text { Adults with mental health } \\
\quad \text { difficulties }\end{array}$ & $\begin{array}{l}\text { All types } \\
\text { Community Further Education }\end{array}$ & $\begin{array}{l}\text { Survey plus depth interviews } \\
\text { Review of studies }\end{array}$ & $\begin{array}{l}\text { Dench \& Regan, } 1999 \\
\text { Wertheimer, } 1997\end{array}$ \\
\hline & England & $\begin{array}{l}\text { Adults with chronic health and/or } \\
\text { employment difficulties }\end{array}$ & Various & Evaluation of a project & McGivney, 1997 \\
\hline & England & Adults & Further education & $\begin{array}{l}\text { Quantitative and qualitative } \\
\text { survey }\end{array}$ & Preston \& Hammond, 2002 \\
\hline & Finland & Adults & Planned learning & Qualitative biographical & Antikainen, 1998 \\
\hline & US & Fit older adults & Level of previous education & Quantitative & Kubzansky et al., 1998 \\
\hline Perceived happiness & US & Older adults & Current education & Qualitative & Mookherjee, 1998 \\
\hline
\end{tabular}


Coping with Stress

Resilience refers to the dimension of individual difference that spans the ways we deal with adversity and stressful conditions and how they affect us (see Garmezy, 1971; Anthony; 1974; Rutter, 1990). The argument here is that education develops psychosocial qualities that contribute to resilience. Howard, Dryden and Johnson (1999) review theoretical and empirical literature relating to the development of resilience amongst children, which is defined by success later in life despite growing up in contexts that include a number of risk factors, for example, poverty, large family size, parental criminality, and poor child-rearing techniques. The authors conclude that the following 'internal attributes' characterise the resilient child: autonomy, problem-solving skills, a sense of purpose and future, and social competence. These 'internal assets' equate-more or less - to the psychosocial outcomes of adult learning discussed above (and see tables 3 and 4).

If organised adult learning contributes to the development of resilience, then it will contribute to greater well-being and to better health. Numerous studies of students in community-based education who have a history of mental health difficulties report that participation has positive effects upon mental health (Wertheimer, 1997; McGivney, 1997). Indeed, some GP practices now prescribe education as treatment for their patients (Wheeler et al., 1999), and such schemes have been piloted and evaluated (James, 2001). Antikainen (1998) conducted biographical interviews each lasting over several days with adults living in Finland and reports that some individuals find learning particularly empowering at times of transition, which are times of high stress relative to periods of stability.

Dealing effectively with adversity and stressful conditions affects physical as well as mental health. Reliance upon nicotine, alcohol and other addictive substances as well as certain patterns of eating are common responses to adversity and stressful conditions (Allison et al., 1999). Individuals who (through education) are more resilient may be inclined to respond in other ways, which are less damaging to their physical health and possibly more effective in reducing levels of experienced stress in the longer term.

Individuals who are more resilient, almost by definition, experience lower levels of chronic stress in response to a given stressor or life event. This will affect health behaviours. It will also have a direct effect upon physical health outcomes. It appears that chronic stress exacts a cost that can both promote the onset of illness and its progression (see Ogden, 1997, and Wilkinson, 1996, for fuller discussions). Levels of experienced stress and self-efficacy may also affect the perception of certain symptoms such as pain (Turk et al., 1983).

As we have seen above and in Table 3, education promotes social integration, civic engagement, and widens social networks. Schlossberg et al. (1995) suggest that social networks and the ability to draw upon social resources contribute to resilience, leading to better psychological and physical health outcomes. Indeed, the positive effects of social integration and social support upon physical and mental health have been widely reported. Longitudinal studies have been used to show that social isolation precedes illness, and that the effects of previous social isolation upon the incidence of illness persist after factors that may affect both social isolation and health are controlled for. Putnam reviews these effects and concludes that

Social connectedness is one of the most powerful determinants of our well-being. The more integrated we are with our community, the less likely we are to experience colds, heart attacks, strokes, cancer, depression, and premature death of all sorts. (2000, p. 326)

In summary, adult learning contributes to the development of resilience, which in turn has positive effects upon mental and physical health. 
However, not all forms of learning have such effects upon every individual. In the review of literature relating to the development of resilience in children referred to above, Howard et al. (1999) suggest that certain aspects of school education promote the development of resilience. These include provision within a setting which is challenging but cooperative, inclusive but heterogeneous, and one which encourages active participation. In a survey of over 10,000 managers and lecturers working in Further Education in England, respondents suggested that very similar aspects of provision are important in generating the psychosocial components of resilience (Preston \& Hammond, 2002). The fieldwork study involving over 140 biographical interviews referred to above (Schuller et al., 2002) includes many examples of learning experiences that undermined self-confidence, autonomy and social confidence, each of which contribute to personal resilience. The authors suggest that an additional aspect of learning that is critical to the development of positive psychosocial qualities is that the content of learning is meaningful to the learner, and that the level of challenge and support suits the learner.

These findings have direct policy implications. In addition, they contribute to understanding of other findings where positive relationships between education and health are not found, for example, in relation to anorexia nervosa and other neurotic disorders (p. 2). It is plausible that individuals who are particularly prone to these disorders may also tend to be educationally successful. In addition, learning in contexts that are highly competitive and not inclusive or supportive may have negative effects upon psychological health.

\section{Conclusions and Discussion}

The purpose of this paper has been to suggest a typology of intermediate factors linking education with health outcomes. The typology is a simplification, because intermediate factors operate together, but they are presented here as a first step towards understanding the processes through which education affects health.

Although the development of the typology was the purpose of the research, the process of doing so led quite incidentally to the identification of policy-relevant issues or themes that apply to all groups of intermediate factors. The first theme is that the immediate psychosocial outcomes of learning play a fundamental role in generating the practices, skills and personal attributes that have early but lasting effects upon mental health and cumulative effects upon physical health.

The second theme is that education is not always associated with better health outcomes amongst all groups of individuals. This raises questions about which aspects of learning are important in relation to health benefits. What appears to make the difference is that education is provided in settings that are cooperative and challenging, heterogeneous and inclusive, and that learning presents the levels of challenge and support that reflect the needs of the learner.

The third theme is that when education benefits the health of individuals, it may or may not also benefit the health of whole communities. Outcomes of education that increase personal resilience and promote the adoption of healthy practices are likely to benefit not only individuals, but whole communities. In contrast, effects of education upon economic status and access to health services improve health at individual but not at collective levels. This is because such effects at best fail to challenge existing socio-economic inequalities, and at worst, reinforce them.

The fourth theme is that the extent to which positive psychosocial qualities (developed through participation in education) translate into psychological and physiological health benefits depends upon the social and economic structures in which learners are situated. If the philosophies underlying the provision of education are at odds with the structures that 
surround the learner, success in education may lead to tensions that can undermine psychological and ultimately physical health. Thus, educational policies should be rationalised with wider social and economic structures. This is a two-way process; educational policies inevitably reflect wider structures, but at the same time, where the political will is present, educational policies can be used to change these structures. For example, inequalities and social exclusion may be addressed by policies that target educational provision towards marginalised groups, and which emphasise those aspects of education that promote critical awareness, empowerment and social inclusion amongst all learners.

In conclusion, what roles can education play in promoting health at both individual and community levels? The answer lies in its potential for developing resilience and social cohesion. These qualities will not only promote healthier lifestyles and reduce levels of experienced stress. They will also lead to the challenging of social and economic inequalities and the generation of a more socially cohesive and health-inducing society.

Correspondence: Cathie Hammond, DfES Research Centre on the Wider Benefits of Learning, Bedford Group for Life Course and Statistical Studies, Institute of Education, Bedford Way, London WC1H 0AL, UK.

\section{Acknowledgements}

I would like to thank John Bynner, Deborah Saffron and Leon Feinstein for their advice and support.

\section{Note}

[1] The research described here was undertaken during the initial phase of the work of the Centre for Research on the Wider Benefits of Learning and was funded by the Department for Education and Skills. The views expressed in this work are those of the author and do not necessarily reflect the views of the Department for Education and Skills. All errors and omissions remain those of the author.

\section{References}

Albelda, R., McRate, E., Melendez, E. \& Lapidus, J. (1988) Mink Coats Don't Trickle Down: the economic attack on women and people of color, Boston, MA, South End Press.

Allison, K.R., Adlaf, E.M., Ialomiteanu, A. \& Rehm, J. (1999) Predictors of health risk behaviours among young adults: analysis of the national population health survey, Canadian Journal of Public Health, 90, 2, 85-89.

Amonkar, M.M., Madhavan, S., Rosenbluth, S.A. \& Simon, K.J. (1999) Barriers and facilitators to providing common preventive screening services in managed care settings, Journal of Community Health, 24, 3, 229-247.

Angell, A.V. (1998) Practicing democracy at school: a qualitative analysis of an elementary class council, Theory and Research in Social Education 26, 2, 149-172.

Anthony, E.J. (1974) The syndrome of the physiologically invulnerable child. In: E.J. Anthony \& B.J. Cohler (eds) The Child in his Family: children at psychiatric risk, International Yearbook (Vol. 3), New York, Wiley.

Antikainen, A. (1998) Between structure and subjectivity: life-histories and lifelong learning, International Review of Education, 44, 2\&3, 215-234.

Asplund, R. \& Pereira, P. (1999) Returns to Human Capital in Europe: a literature review, Helsinki, The Research Institute of the Finnish Economy/Taloustieto Oy.

Banks, M., Bates, I., Breadkwell, G., Bynner, J., Emler, N., Jamieson, L. \& Roberts, K. (1992) Careers and Identities, Milton Keynes, Open University Press. 
Becker, G.S. \& Mulligan, C.B. (1994) On the Endogenous Determination of Time Preference, George G. Stigler Center for Study of Economy and State Series Paper 98, University of Chicago.

Benham, L. \& Benham, A. (1982) Employment, earnings, and psychiatric diagnosis. In: V.R. Fuchs (eds) Economic Aspects of Health, NBER, University of Chicago Press.

Berggren, F. \& Sutton, M. (1999) Are frequency and intensity of participation decisionbearing aspects of consumption? An analysis of drinking behaviour, Applied Economics, 31 , 7, 865-874.

Braddon, F.E.M., Wadsworth, M.E.J., Davies, J.M.C. \& CRipps, H.A. (1988) Social and regional differences in food and alcohol consumption and their measurement in a National Birth Cohort, Journal of Epidemiology and Community Health, 42, 341-349.

Buchwald, D., Umali, J., Umali, P., Kith, P., Pearlman, T. \& Komaroff, A. (1995) Chronic fatigue and the chronic fatigue syndrome: prevalence in a Pacific Northwest Health Care System, Annals of Internal Medicine, 123, 81-88.

Bynner, J. \& AshFord, S. (1994) Politics and participation: some antecedents of young people's political activity and disaffection, European Journal of Social Psychology, 24, 223-226.

Bynner, J. \& Egerton, M. (2001) The Wider Benefits of Higher Education, Report 01/46, Bristol, HEFCE.

CALLAGHan, P. (1998) Social support and locus of control as correlates of UK nurses' healthrelated behaviours, Journal of Advanced Nursing, 28, 5, 1127-1133.

Campbell, C. \& Mzaidume, Z. (2001) Grassroots participation, peer education, and HIV prevention by sex workers in South Africa, American Journal of Public Health, 9, 12, $1978-1986$.

Campbell, C. \& Mzaidume, Z. (2002) How can HIV be prevented in South Africa? A social perspective, British Medical Journal, 324, 229-232.

Carlton, S. \& Soulsby, J. (1999) Learning to Grow Older and Bolder, Leicester, NIACE.

Clark, A.E. \& Oswald, A.J. (1994) Unhappiness and unemployment, Economic Journal, 104, $648-649$.

Costakis, C.E., Dunnagen, T. \& Haynes, G. (1999) The relationship between stages of exercise adoption and other health behaviors, American Journal of Promotion, 14, 1, 22-30.

Cox, R. \& Pascall, G. (1994) Individualism, self-evaluation and self-fulfilment in the experience of mature women students, International Journal of Lifelong Education, 13, 2, 159-173.

CRISP, A.H. (1980) Anorexia Nervosa: let me be, London, Academic Press Inc.

Crossley, M.L. (2000) Rethinking Health Psychology, Buckingham, Open University Press.

Daldy, P., Gomez, J. \& IsaAcs, A.J. (1979) Anorexia Nervosa, William Heinemann Medical Books Ltd, London.

Dench, S. \& Regan, J. (1998) Learning in Later Life: motivation and impact. Report issued by the Institute for Employment Studies.

Desai, S. (1987) The Estimation of the Health-Production Function for Low-Income Working Men, Medical Care, 25, 604-615.

Emler, N. \& Fraser, E. (1999) Politics, the education effect, Oxford Review of Education, 25, 1\&2, $251-273$.

Ennis, C.D., Solomon, M.A., Satina, B., Loftus, S.J., Mensch, J., McCauley, M.T. (1999) Creating a sense of family in urban schools using the 'Sport for Peace' curriculum, Research Quarterly for Exercise and Sport, 70, 3, 273-285.

Feigelman, W., Wallisch, L.S., Lesieur, H.R. (1998) Problem gamblers, problem substance users, and dual-problem individuals: an epidemiological study, American Journal of Public Health, 88, 3, 467-470.

Feinstein, L. (2001) Review of Quantified Evidence on the Wider Benefits of Learning and Related Potential Costs and Savings: crime and health. Report to the Treasury/DfES.

Feinstein, L. (2002) Quantitative estimates of the social benefits of learning, 2: health (depression and obesity), London, Wider Benefits of Learning Research Report No.6. 
FInK, R.H. (1982) Supply-side Economics: a critical appraisal, Frederick, MD, University Publications of America.

Frisk, J., Brynhidsen, J., Ivarsson, T., Persson, P. \& Hammar, M. (1997) Exercise and smoking habits among Swedish postmenopausal women, British Journal of Sports Medicine, 31, 3, 217-223.

GARMEZY, N. (1971) Vulnerability research and the issue of primary prevention, Journal of Orthopsychiatry, 41, 101-116.

Glaeser, E.L. (1999), The Formation of Social Capital. Paper delivered at OECD/Canada Statistics Conference on 'Human and Social Capital', Quebec, March.

Gordon, A. (1990) Eating Disorders: anatomy of a social epidemic, Oxford, Blackwell Publishers.

Grossman, M. (1975) The correlation between health and schooling, in: N.E. TerLecKYI (ed.) Household Production and Consumption, Studies in Income and Wealth, 40, Conference on Research in Income and Wealth, New York, Columbia University Press for the National Bureau of Economic Research.

Grossman, M. \& Kaestner, R. (1997) Effects of education on health, in: J.R. Behrman \& N. StaCey (eds) The Social Benefits of Education, Ann Arbor, MI, University of Michigan Press.

Hagoel, L., Ore, L., Neter, E., Shifroni, G. \& Rennert, G. (1999) The gradient in mammography screening behavior: a lifestyle marker, Social Science and Medicine, 48, 9, 1281-1290.

Hammond, C. (2002) Learning to be Healthy, The Wider Benefits of Learning Papers, London, Institute of Education.

Hammond, C. \& Preston, J. (2002) The Wider Benefits of Further Education: Practitioner Views, Wider Benefits of Learning Research Report, London, Institute of Education.

HART, J.T. (1971) The inverse care law, Lancet, 1, 405-412.

Hartog, J. \& Oosterbeek, O. (1998) Health, wealth and happiness: why pursue a higher education? Economics of Eduction Review, 17, 3, 245-256.

Heinrich, J., Popescu, M.A., Wist, M., Goldstein, I.F. \& Winchmann, H.E. (1998) Atopy in children and parental social class, American Journal of Public Health, 88, 9, 1319-1324.

Hemmingway, H., Shipley, M., Macfarlane, P. \& Marmot, M. (2000) Impact of socioeconomic status on coronary mortality in people with symptoms, electrocardiographic abnormalities, both or neither: the original Whitehall study 25 year follow up, Journal of Epidemiology and Community Health, 54, 510-516.

Hirsch, F. (1977) Social Limits to Growth, London, Routledge.

Howard, S., Dryden, J. \& Johnson, B. (1999) Childhood resilience: review and critique of literature, Oxford Review of Education, 25, 3, 307-323.

Huld, B. (1998) Education for psychological health, Adults Learning, September, 15-17.

Ippolito, P.M. \& Mathios, A.D. (1990) Information, advertising and health choices-a study of the cereal market, RAND Journal of Economics, 21, 3, 459-480.

JAMEs, K. (2001) 'Prescriptions for Learning' Evaluation Report, Leicester, NIACE.

JARvis, P. \& WALKER, J. (1997) When the process becomes the product: summer universities for seniors, Education and Ageing, 12, 60-68.

Johnes, G. (1993) The Economics of Education, London, Macmillan.

Jorm, A.F., Rodgers, B., Jacomb, P.A., Cristensen, H., Henderson, S. \& Korten, A.E. (1999) Smoking and mental health: results from a community survey, Medical Journal of Australia, $170,2,74-77$.

Karvonen, S., Rimpela, A.H. \& Rimpela, M.I. (1999) Social mobility and health related behaviours in young people, Journal of Epidemiology and Community Health, 53, 4, 211-217.

Kasenda, M., Calzavara, L.M., Johnson, I. \& Leblanc, M. (1997) Correlates of condom use in the young adult population of Ontario, Canadian Journal of Public Health, 88, 4, 280-285.

Kendler, K.S., Neale, M.C., Sullivan, P., Corey, L.A., Gardner, C.O. \& Prescott, C.A. (1999) A population-based twin study in women of smoking initiation and nicotine dependence, Psychological Medicine, 29, 2, pp. 299-308. 
Kenket, D.S. (1991) Health behavior, health knowledge and schooling, Journal of Political Economy, 99, 287-305.

Kickвusch, I. (1990) A Strategy for Health Promotion, WHO Regional Office for Europe, Copenhagen.

Kippax, S. \& Crawford, J. (1993) Flaws in the theory of reasoned action. In: D. Terry, C. Gallois \& M. McCamish (eds) The Theory of Reasoned Action: its application to AIDS-preventive behaviour, Oxford, Pergamon.

Koberg, C.S., Boss, R.W. \& Goodman, E. (1998) Factors and outcomes associated with mentoring among health-care professionals, Journal of Vocational Behavior, 53, 1, $58-72$.

Kocken, P.L. \& Voorham, A.J.J. (1998) Effects of a peer-led senior health education program, Patient Education and Counseling, 34, 1, 15-23.

Krugman, P. (1994) Peddling Prosperity: economic sense and nonsense in the age of diminished expectations, New York, Norton \& Company.

Kubzansky, L.D., KaWachi, I. \& Sparrow, D. (1999) Socioeconomic status, hostility, and risk factor clustering in the normative aging study: any help from the concept of allostatic load? Annals of Behavioral Medicine, 21, 4, 330-338.

Kyngas, H. \& Lahdenpera, T. (1999) Compliance of patients with hypertension and associated factors, Journal of Advanced Nursing, 29, 4, 832-839.

Lawrie, S. \& Pelosi, A. (1995) Chronic fatigue syndrome in the community: prevalence and associations, British Journal of Psychiatry, 166, 793-797.

Leigh, J.P. (1990) Schooling and seat-belt use, Southern Economic Journal, 57, 1, 195-207.

Leighton, K.M. \& Millar, H.R. (1985) Anorexia nervosa in Glasgow, Journal of Psychiatric Research, 19, pp. 167-170.

Marmot, M.G., Smith, G.D., Stansfield, S., Patel, C., North, F., Head, J., White, I., Brunner, E. \& FeEneY, A. (1991) Health inequalities among British civil servants: the Whitehall II study, Lancet, 337, 8754, 1387-1393.

McGivney, V. (1997) Evaluation of the Gloucester Primary Health Care Project, GLOSCAT, unpublished report.

Mirowsky, J. \& Ross, C.E. (1998) Education, personal control, lifestyle and health-a human capital hypothesis, Research on Ageing, 20, 4, 415-449.

MookherJee, H.N. (1998) Perception of happiness among elderly persons in metropolitan USA, Perceptual and Motor Skills, 87, pp. 787-793.

Ogden, J. (1997) Health Psychology: a textbook, Buckingham, Open University Press.

Parry, G., Moyser, G. \& Day, N. (1992) Political Participation and Democracy in Britain, Cambridge, Cambridge University Press.

Pearlin, L.I., Lieberman, M.A., Menaghan, E.G. \& Mullan, J.T. (1981) The Stress Process, Journal of Health and Social Behavior, 22, 337-356.

Peyrot, M., McMurry, J.F. \& Kruger, D.F. (1999) A biopsychosocial model of glycemic control in diabetes: stress, coping and regimen adherence, Journal of health and sopcial behavior, 40, 2, 141-158.

Preston, J. \& Hammond, C. (2002) The Wider Benefits of Further Education: Practitioner Views, Wider Benefits of Learning Research Report, London, Institute of Education.

Putnam, R.D. (2000) Bowling Alone: the collapse and revival of American community, New York, Simon \& Schuster.

Rini, C.K., Dunkelschetter, C., Wadhwa, P.D. \& Sandman, C.A. (1999) Psychological adaptation and birth outcomes: the role of personal resources, stress, and sociocultural context in pregnancy, Health Psychology, 18, 4, 333-345.

Ross, C.E. \& Mirowsky, J. (1999) Refining the association between education and health: the effects of quantity, credential, and selectivity, Demography, 36, 4, 445-460.

Rudman, L.A., Gonzales, M.H. \& Borgida, E. (1999) Mishandling the gift of life: noncompliance in renal transplant patients, Journal of Applied Social Psychology, 29, 4, 834-851. 
Rutter, M. (1990) Psychosocial resilience and protective mechanisms, in: J. Rolf, A. Masten, D. Cicchetti, K. Neuchterlein \& S. Weintraub (eds) Risk and Protective Factors in the Development of Psychopathology, New York, Cambridge University Press.

SAnder, W. (1995a) Schooling and quitting smoking, Review of Economics and Statistics, 77, 191-199.

SANDER, W. (1995b), Schooling and Smoking, Economics of Education Review, 14, 23-33.

Schafer, E., Schafer, R.B., Keith, P.M. \& Bose, J. (1999) Self-esteem and fruit and vegetable intake in women and men, Journal of Nutrition Education, 31, 3, 153-160.

Schlossberg, N.K., Waters, E.B. \& Goodman, J. (1995) Counselling Adults in Transition: linking practice with theory, New York, Springer.

Schuller, T., Brassett-Grundy, A., Green, A., Hammond, C. \& Preston, J. (2002) Learning, Continuity and Change in Adult Life, Wider Benefits of Learning Research Report, London, Institute of Education.

Seeman, M. \& Lewis, S. (1995) Powerlessness, Health and Mortality: a longitudinal study of older men and mature women, Social Science and Medicine, 41, 517-525.

Seeman, M., Seeman, A.Z. \& Budros, A. (1988) Powerlessness, work and community: a longitudinal study of alienation and alcohol use, Journal of Health and Social Behavior, 29, $185-198$.

Seeman, M. \& Seeman, T.E. (1983) Health Behavior and Personal Autonomy: a longitudinal study of older men and mature women, Social Science and Medicine, 41, 517-525.

Shefer, A., Dobbins, J. \& Fukuda, K. et al. (1997) Fatiguing illness among employees in three large state office buildings, California, 1993: was there an outbreak? Journal of Psychosomatic Research, 31, 31-43.

Teisl, M.F., Lew, A.S. \& Derby, B.M. (1999) The effects of education and information source on consumer awareness of diet-disease relationships, Journal of Public Policy and Marketing, $18,2,197-207$.

Toro, K., Nicolau, R., Cervera, M., Castro, J., Blecua, M.J., Zaragoza, M. \& Toro, A. (1995) A clinical and phenomenological study of 185 Spanish adolescents with anorexianervosa, European Child and Adolescent Psychiatry, 4, 3, 165-174.

Turk, D.C., Meichenbaum, D. \& Genest, M. (1983) Pain and Behavioural Medicine, New York, Guildford Press.

Van Oers, J.A.M., Bongers, I.M.B., Van de Goor, L.A.M. \& Garretsen, H.F.L. (1999) Alcohol consumption, alcohol-related problems, problem drinking, and socio-economic status, Alcohol and Alcoholism, 34, 1, 78-88.

WAGNER, U. \& ZICK, A. (1995) The relation of formal education to ethnic prejudice: its reliability, validity and explanation, European Journal of Social Psychology, 25, 1, 41-56.

Wertheimer, A. (1997) Images of possibility: creating learning opportunities for adults with mental health difficulties, Leicester, NIACE.

Wessely, S., Hotoph, M. \& Sharpe, M. (1998) Chronic Fatigue and its Syndromes, Oxford, Oxford University Press.

West, L. (1995) Beyond fragments: adults, motivation and higher education, Studies in the Education of Adults, 27, 2.

Wheeler, M., Smith, F. \& Trayhorn, L. (1999) Improving health through referral to adult education. Report produced by the Kingston and Richmond Health Authority and the Royal Borough of Kingston-upon-Thames.

WiLKinson, R.G. (1996) Unhealthy Societies: the afflictions of inequality, London, Routledge. 